\title{
Development of Safflower Subjected to Nitrogen Rates in Cerrado Soil
}

\author{
Edna Maria Bonfim-Silva*, Juliana Terezinha Sasso Paludo, \\ Jackelinne Valéria Rodrigues Sousa, Helon Hébano de Freitas Sousa, \\ Tonny José Araújo da Silva
}

Department of Agricultural and Environmental Engineering, Institute of Agricultural Sciences and Technology, Federal University of MatoGrosso, Rondonópolis, Brazil

Email: embonfim@hotmail.com

Received 29 July 2015; accepted 23 August 2015; published 28 August 2015

Copyright (C) 2015 by authors and Scientific Research Publishing Inc.

This work is licensed under the Creative Commons Attribution International License (CC BY). http://creativecommons.org/licenses/by/4.0/

(c) (i) Open Access

\begin{abstract}
In a context in which the nitrogen fertilizer recommendations in the literature for safflower crop show up conflicting, it was aimed by the present study to evaluate the development of safflower when subjected to nitrogen rates in an Oxisol collected under Cerrado vegetation. The experiment was conducted in a greenhouse using pots filled with oxisol collected in area under Cerrado vegetation in the layer from 0.0 to $0.20 \mathrm{~m}$. Each experimental unit was represented by a plastic pot of 5 $\mathrm{dm}^{-3}$, the experimental design was completely randomized, consisting of six nitrogen rates $(0,60$, 120, 180, 240 and $300 \mathrm{mg} \cdot \mathrm{dm}^{-3}$ ) and six repetitions. It were assessed plant height, number of leaves, chlorophyll content, number of heads, dry mass of shoot and dry mass of root. The results were submitted to variance analysis and, when significant, to regression analysis, both at $5 \%$ probability by SISVAR program. Nitrogen rates positively influence the development of safflower, and the one that best promotes this development is between 160 and $190 \mathrm{mg} \cdot \mathrm{dm}^{-3}$.
\end{abstract}

\section{Keywords}

Cathamus tintorius L., Biodiesel Alternative, Nitrogen

\section{Introduction}

Due to the imminent depletion of fossil fuel resources, the search for alternatives has increased and oilseeds such as soybeans (Glycine max L), sunflower (Helianthus annuus), palm oil (Elaeis guineensis Jacq.), coconut (Cocos nucifera L.), canola (Brassica napus L.) and safflower (Carthamus tinctorius L) currently occupy a

${ }^{*}$ Corresponding author.

How to cite this paper: Bonfim-Silva, E.M., Paludo, J.T.S., Sousa, J.V.R., de Freitas Sousa, H.H. and da Silva, T.J.A. (2015) Development of Safflower Subjected to Nitrogen Rates in Cerrado Soil. American Journal of Plant Sciences, 6, $2136-2143$. http://dx.doi.org/10.4236/ajps.2015.613215 
prominent place in research related to substitutes as raw material for biofuel production.

Although little known in some parts of the world, the safflower is grown for thousands of years and has been used for many different purposes; as coloring materials, for example, it has been noticed since ancient times in Egypt, Morocco and China [1] and even today there is research in this area [2] [3]. It's also used in medicine [4] and on human and industrial use since the seeds of this plant species have high oil contents (35\% to $40 \%$ ) of good quality [5].

There are quotes about the culture rusticity in which it figures as a plant resistant to water deficit [6], high temperatures and saline soils [7]. These characteristics encourage and justify its cultivation in hot climate regions and with intervals spaced between the rainy season, as the Semi-Arid and the Brazilian Cerrado.

Despite the plant growing characteristics being known for various situations, when there is involvement of natural and financial resources, it is compulsory to know deeply all the nuances of the production process before introducing a new economic culture in a region.

Nitrogen fertilization is a good example to show the need for more research in the area, the reference [8] indicates the dose of $200 \mathrm{~kg}$ of nitrogen for each cultivated hectare as the optimal fertilizer for the crop to reach the best of its potential. However, unlike these authors, the reference [9] suggests a recommendation of nitrogen rates of $150 \mathrm{~kg} \cdot \mathrm{ha}^{-1}$.

Other authors have shown to be more cautious and do not suggest a fixed dose, but a range in which one can get the maximum crop production, the reference [10] suggests a dose of $80-120 \mathrm{~kg} \cdot \mathrm{ha}^{-1}$ and the reference [11], the dose of $125-175 \mathrm{~kg} \cdot \mathrm{ha}^{-1}$ of nitrogen. Growing in pots and in greenhouse conditions, the reference [12] finds the dose of $95 \mathrm{mg} \cdot \mathrm{dm}^{-3}$ as the one that promotes the best development for safflower culture. There are papers as the one of the reference [13], in which the fertilization with nitrogen did not increase crop yield.

Although it seems that there is no consensus on the amount of nitrogen to be used, more than that, the different figures show there are peculiarities that must be taken into consideration when recommending the fertilizer, as soil type, environmental conditions, growing season, earlier cultures, among others.

In this context, the aim of the present study was to evaluate the development of safflower when subjected to nitrogen doses in an Oxisol collected under Cerrado vegetation.

\section{Materials and Methods}

The study was conducted in a greenhouse on the campus of the Federal University of Mato Grosso, Rondonópolis, central Brazil, $16^{\circ} 27^{\prime} 52^{\prime \prime} \mathrm{S}$ and $54^{\circ} 34^{\prime} 46^{\prime \prime} \mathrm{W}$ at $284 \mathrm{~m}$ of altitude, with an Aw climate type, Koppen classification. The soil was collected in a layer of $0.0-0.20 \mathrm{~m}$ of an Oxisol from an area under Cerrado vegetation, sifted in a mesh of $4 \mathrm{~mm}$ to fill the pots and in a $2 \mathrm{~mm}$ mesh for chemical and granulometric characterization (Table 1). The soil $\mathrm{pH}$ was corrected with dolomitic lime incorporation (PRNT $=80.3 \%$ ), for 20 days, rising base saturation to the level of $60 \%$.

Each experimental unit was represented by a plasticpot of $5 \mathrm{dm}^{3}$, the experimental design was completely randomized, consisting of six nitrogen rates $\left(0,60,120,180,240\right.$ and $\left.300 \mathrm{mg} \cdot \mathrm{dm}^{-3}\right)$ and six repetitions.

The basic planting fertilization was performed after limestone incubation, being incorporated into the soil in solid, granular form, 80 and $100 \mathrm{mg} \cdot \mathrm{dm}^{-3}$ potassium $\left(\mathrm{K}_{2} \mathrm{O}\right)$ and phosphorus $\left(\mathrm{P}_{2} \mathrm{O}_{5}\right)$, respectively, having potassium chloride and superphosphate as sources. The nitrogen source used was urea, $30 \%$ of the dose applied at planting and $70 \%$ at 15 days after seedling emergence.

Sowing was performed using 5 seeds per pot and, after 10 days, chopped, leaving only two plants. Irrigation was performed using the gravimetric method remaining $60 \%$ of the maximum capacity of water retention during the development of the experiment according to the reference [14].

The plant height variable was measured with a ruler graduated from the ground level to the highest part of

Table 1. Chemical and granulometric characterization in the layer of $0-0.20 \mathrm{~m}$, of the Oxisol.

\begin{tabular}{|c|c|c|c|c|c|c|c|c|c|c|c|c|c|}
\hline $\mathrm{pH}$ & $\mathrm{P}$ & K & $\mathrm{Ca}$ & $\mathrm{Mg}$ & $\mathrm{H}$ & $\mathrm{Al}$ & SB & CEC & V & O.M. & Sand & Silt & Clay \\
\hline $\mathrm{CaCl}_{2}$ & \multicolumn{2}{|c|}{$\mathrm{mg} \cdot \mathrm{dm}^{-3}$} & & \multicolumn{4}{|c|}{ - } & & $\%$ & $\mathrm{~g} \cdot \mathrm{dm}^{-3}$ & \multicolumn{3}{|c|}{------- g.kg-1 -------- } \\
\hline 4.1 & 2.4 & 28 & 0.3 & 0.2 & 4.2 & 1.1 & 0.6 & 5.9 & 9.8 & 22.7 & 549 & 84 & 367 \\
\hline
\end{tabular}

Calcium Chloride $\left(\mathrm{CaCl}_{2}\right)$, Phosphorus (P), Potassium (K), Calcium (Ca), Magnesium (Mg), Hydrogen (H), Aluminum (Al), Sum of Bases (SB), CationExchange Capacity (CEC), Base Saturation (V) and Organic Matter (O.M). 
each plant. The number of leaves had their data collected at 25, 45 and 65 days after sowing (DAS). The chlorophyll content was measured at 65 DAS with portable chlorophyll meter, brand Falker ClorofiLOG ${ }^{\circledR}$ model $^{-}$ CFL 1030.

The dry mass of shoot and root were obtained from the material collected after cutting the plants at 65 DAS. The material was packaged in paper bags and taken to dry in forced-air oven at $65^{\circ} \mathrm{C}$ until constant weight. Then, the dried samples were weighed in a semi-analytical balance. The roots, before being taken to the greenhouse, were previously washed in running water for complete removal of soil.

The results were submitted to variance analysis and, when significant, to the regression test, both at $5 \%$ probability. The statistical program used was SISVAR [15].

\section{Results and Discussion}

There was influence of nitrogen doses in all variables observed with the effect of nitrogen described by quadratic regression model, regardless of the time of observation. The larger safflower plant heights were 24.34 (25 DAS), 68.25 (45 DAS) and $81.67 \mathrm{~cm}(65 \mathrm{DAS})$ at the doses of 85, 100 and $113.33 \mathrm{mg} \cdot \mathrm{dm}^{-3}$, respectively (Figure 1).

The data corroborate those of the reference [10], in which safflower plants reacted similarly to nitrogen application. These authors obtained positive responses to the nitrogen dose of $120 \mathrm{~kg} \cdot \mathrm{ha}^{-1}$, when the plants reached height of $125 \mathrm{~cm}$. The reference [16], evaluating the height of sunflower plants grown under irrigation in Quartzipsamment Neosol found, at 45 DAS, the height of $114.7 \mathrm{~cm}$ for the nitrogen dose of $72.9 \mathrm{~kg} \cdot \mathrm{ha}^{-1}$.

The highest speed of vegetative growth was observed in the period between 25 and 45 DAS. Safflower has slow growth during the first three weeks, this phase is followed by another of greater intensity of growth that lasts until the flowering [17].

It may be noted that the optimal dose of nitrogen that resulted in the highest growth rate varied with time (Table 2). These results demonstrate that as the plant grows the demand for nitrogen is increased due to the involvement of this nutrient in the vegetative part of the culture.

For the number of leaves, the largest observations were 24.97 (25 DAS), 103.06 (45 DAS) and 178.27 (65 DAS) leaves in the nitrogen doses of $118.33 ; 132.50$ and $162.42 \mathrm{mg} \cdot \mathrm{dm}^{-3}$, respectively (Figure 2). The increase in the number of leaves was more significant in the period between 45 and 65 days, when the plants under nitrogen doses in the range of 120 and $180 \mathrm{mg} \cdot \mathrm{dm}^{-3}$ increased by more than $50 \%$ in the number of leaves compared with the treatment without nitrogen fertilization (Table 3).

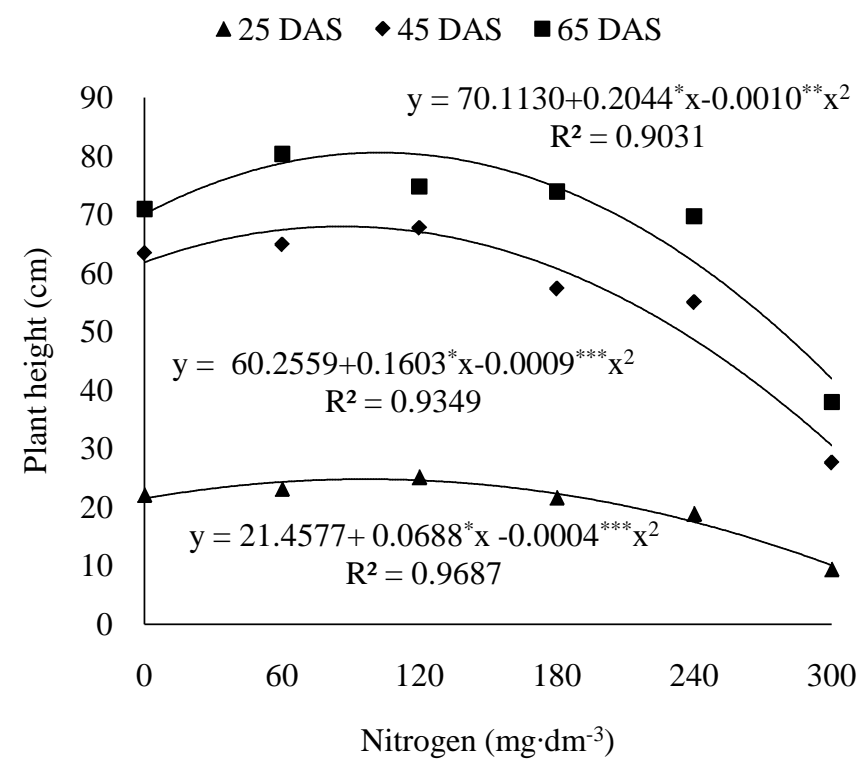

Figure 1. Height of safflower plants subjected to nitrogen doses in an Oxisol of the Cerrado at 25, 45 and 65 DAS. ${ }^{* * *},{ }^{* *},{ }^{*}$ significant at $0.1 \% ; 1 \%$ and $5 \%$, respectively. 


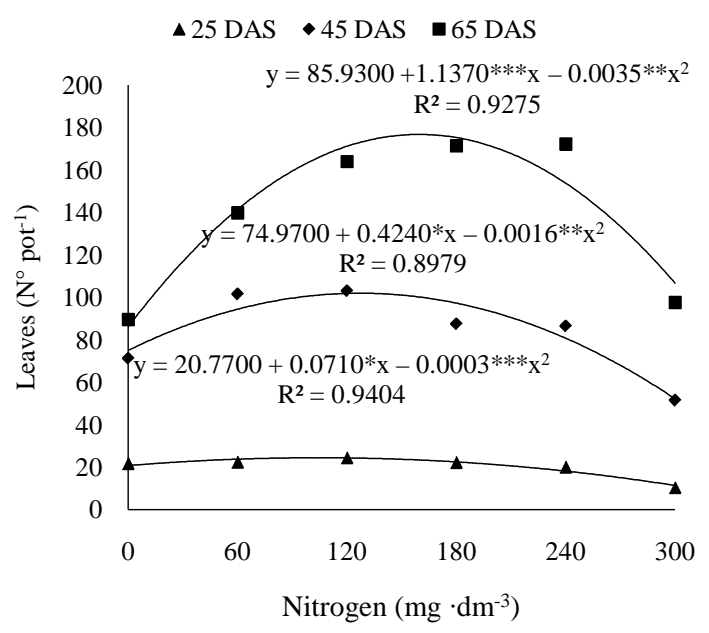

Figure 2. Number of leaves of safflower plants subjected to nitrogen doses in an Oxisol of the Cerrado at 25, 45 and 65 DAS. ${ }^{* * *},{ }^{* *},{ }^{*}$ significant at $0.1 \% ; 1 \%$ and $5 \%$, respectively.

Table 2. Nitrogen doses that provided maximum plant height and increase at 25, 45 and 65 DAS.

\begin{tabular}{cccc}
\hline & 25 DAS & 45 DAS & 65 DAS \\
\hline Dose of Nitrogen $\left(\mathrm{mg} \cdot \mathrm{dm}^{-3}\right)$ & 85 & 100 & 113.33 \\
Greater Height $(\mathrm{cm})$ & 24.34 & 68.25 & 81.66 \\
Increment $^{1}(\%)$ & 11.87 & 13.28 & 16.49 \\
\hline
\end{tabular}

${ }^{1}$ The increment value was obtained when compared the nitrogen dose providing the largest height with the treatment that did not receive nitrogen application. The values were obtained based on the derivative of the adjustment equation.

Table 3. Nitrogen dose that provided a larger number of leaves and an increase at 25, 45, and 65 DAS.

\begin{tabular}{cccc}
\hline & 25 DAS & 45 DAS & 65 DAS \\
\hline Nitrogen dose $\left(\mathrm{mg} \cdot \mathrm{dm}^{-3}\right)$ & 118.33 & 132.50 & 162.42 \\
Number of leaves & 24.97 & 103.06 & 178.27 \\
Increment $^{2}(\%)$ & 16.82 & 27.34 & 51.79 \\
\hline
\end{tabular}

${ }^{2}$ The increment value was obtained when compared the dose of nitrogen that provided the highest height with the treatment that did not receive nitrogen application. The values were obtained based on the derivative of the adjustment equation.

The studies of the number of leaves in scientific research are important because large leaves and in greater number directly influence the interception of the incident sunlight, promoting greater carbon assimilation, maybe contributing in the final dry mass production [18]. Works with nitrogen fertilization in sunflower show a significant increase in the number of leaves as the nitrogen doses increased [16]-[19].

At 65 DAS, the safflower plants showed the highest chlorophyll content (68.19) in the nitrogen dose of 186 $\mathrm{mg} \cdot \mathrm{dm}^{-3}$, with an increase of $50.73 \%$ compared to the treatment that did not receive nitrogen application (Figure 3).

According to the reference [20], the foliar chlorophyll content is indicative of the nutritional status of the plant, for being the nitrogen one of the main elements of the molecular structure of chlorophyll, it can thus demonstrate the need for applying this nutrient.

The influence of nitrogen in the chlorophyll content was observed by the reference [21], who found significant effect on the chlorophyll content of safflower plants in bloom due to nitrogen fertilization, where the two doses studied, 100 and $200 \mathrm{~kg} \cdot \mathrm{ha}^{-1}$, provided a higher amount of chlorophyll content (66.3 and 66.7, respectively) when compared to the treatment without nitrogen fertilizer (62.0).

Regarding the number of heads, the largest production (17.52) was observed in the nitrogen dose of 190 $\mathrm{mg} \cdot \mathrm{dm}^{-3}$, in which the increase compared between the dose that provided larger number of heads and the one 
that had not received fertilization with nitrogen was of $61.79 \%$ (Figure 4).

The number of heads per plant may be one of the yield components that have more influence on the final production of safflower. The reference [22] found a higher number of heads per plant in the nitrogen rate of 80 $\mathrm{kg} \cdot \mathrm{ha}^{-1}$, yet the reference [10] obtained better results in the dose of $120 \mathrm{~kg} \cdot \mathrm{ha}^{-1}$, with production of 7.5 heads per plant.

The highest production of dry mass of shoots (28.08 g) and roots (25.98 g) was found in plants subjected to the nitrogen dose of 174.4 and $177.02 \mathrm{mg} \cdot \mathrm{dm}^{-3}$, respectively (Figure 5).

The production of dry mass is related to the nitrogen supply, since the lack of nitrogen has limited the development of safflower plants, influencing the production of dry mass of shoots. Therefore, when the supply of this nutrient is low there is less production of dry mass, especially leaves, which affects the production of photo assimilates and the distribution of assimilates to the reproductive organs [23].

The reference [13] did not obtain positive responses to increased nitrogen fertilization in safflower. Unlike the results obtained by these authors, this study shows that although the absence of nitrogen fertilization has not prevented the development of culture, the smallest dose of the nutrient is able to promote yield increase, in some cases, as the number of leaves (optimal dose), with the amount being $50 \%$ higher than what is observed in the control.

In this study, it can be seen that the excess of nitrogen was more damaging, for most variables, than the absence of nitrogen fertilization. This is due, possibly, to the nutritional imbalance in relation to other nutrients.

The nitrogen rates in which the variables expressed their greatest value differed between them (Table 4). The

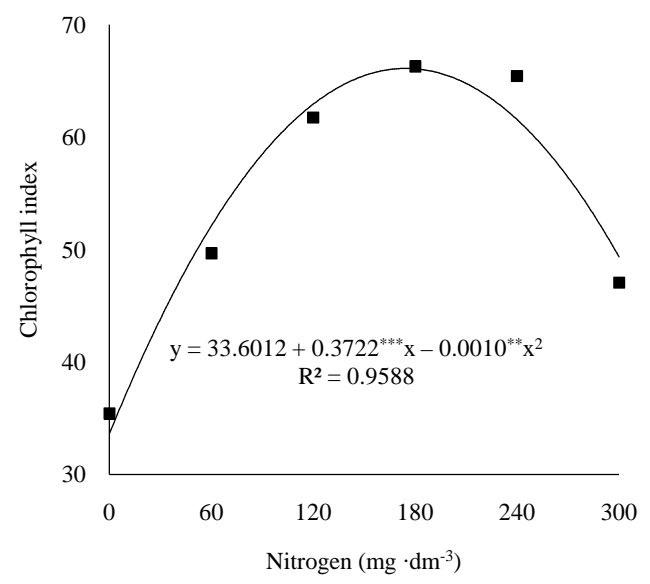

Figure 3. Chlorophyll index of safflower plants subjected to nitrogen doses in an Oxisol of the Cerrado at 65 DAS. ${ }^{* * *}$ and $^{* *}$ significant at $0.1 \%$ and $1 \%$ respectively.

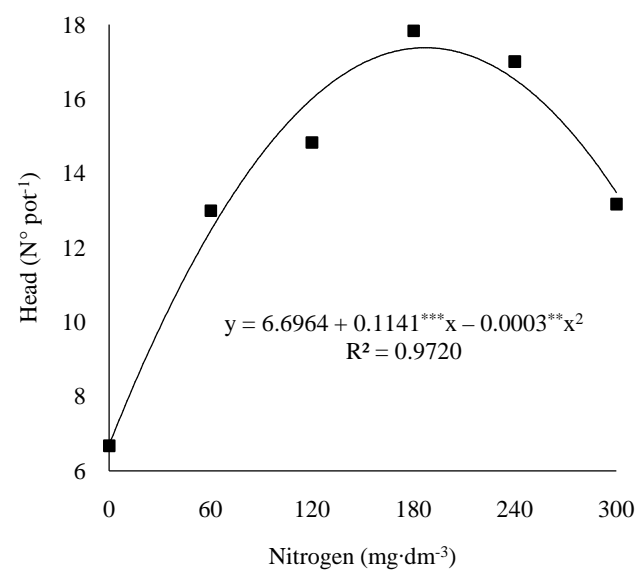

Figure 4. Number of heads of safflower plants subjected to nitrogen doses in an Oxisol of the Cerrado at 65 DAS. ${ }^{* * *}$ and $^{* *}$ significant at $0.1 \%$ and $1 \%$ respectively. 


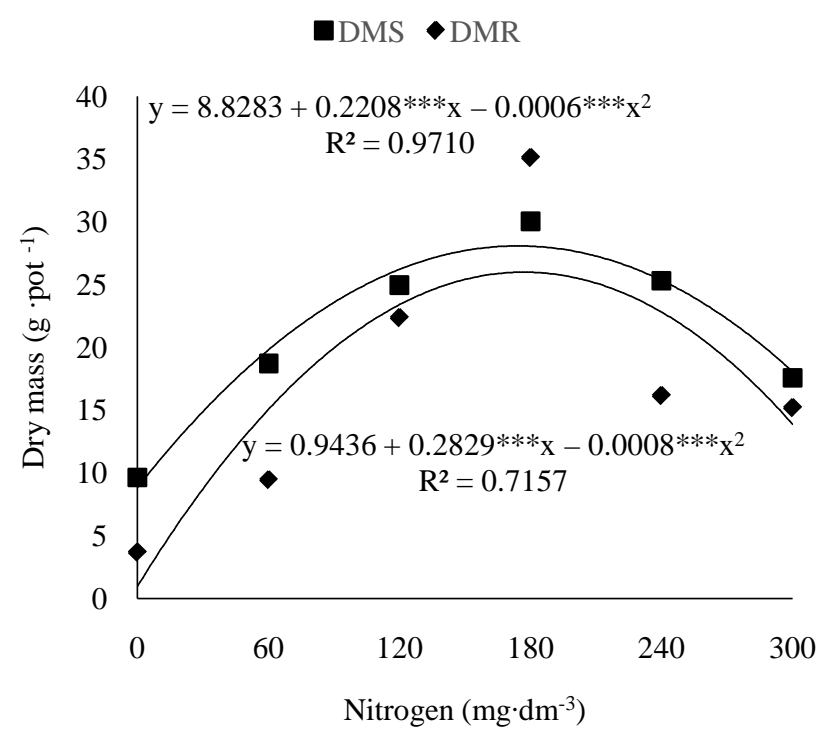

Figure 5. Dry mass of shoot (DMS) and root (DMR) of safflower plants subjected to nitrogen doses in an Oxisol of the Cerrado at 65 DAS. ${ }^{* * *}$ significant at $0.1 \%$.

Table 4. Nitrogen dose $^{3}(\mathrm{~N})$ for maximum production of variables observed at 65 days.

\begin{tabular}{ccc}
\hline Nitrogen dose $\left(\mathrm{mg} \cdot \mathrm{dm}^{-3}\right)$ & Variable observed & Maximum production \\
\hline 113.33 & Height of plants & $81.67 \mathrm{~cm}^{-3}$ \\
162.00 & Number of leaves & 176.27 leaves pot \\
186.00 & Chlorophyll index & 68.19 \\
190.00 & Number of head & 17.52 units pot $^{-1}$ \\
174.40 & Dry mass of shoot & $28.08 \mathrm{~g} \mathrm{pot}^{-1}$ \\
177.02 & Dry mass of root & $25.98 \mathrm{~g} \mathrm{pot}^{-1}$ \\
\hline
\end{tabular}

${ }^{3}$ The values were obtained based on the derivative of the adjustment equation.

lowest dose of nitrogen able to cause a variable to express its highest value was of $113.33 \mathrm{mg} \cdot \mathrm{dm}^{-3}$, wherein the higher plant height was observed. This variable alone cannot necessarily indicate higher production of a culture. The dry mass accumulation, for example, depends not only on plant height, but also on the development of the branches [24]. To indicate a great dose of nitrogen based on this variable does not seem to be assertive.

For all other variables, the nitrogen doses for the best result were higher than that which gave the highest plant height, although different among them. In this case, to set a single dose may not be the ideal, for being the nitrogen dose recommended for safflower production considerably dependent on environmental conditions [11][22].

\section{Conclusion}

Nitrogen fertilization influences the growth, development and production of safflower. For the culture of safflower grown under Oxisol and under controlled conditions, the dose that best promotes the development of safflower is between 160 and $190 \mathrm{mg} \cdot \mathrm{dm}^{-3}$.

\section{References}

[1] Ekin, Z. (2005) Resurgence of Safflower (Carthamus tinctorius L.) Utilization: A Global View. Journal of Agronomy, 4, 83-87. http://dx.doi.org/10.3923/ja.2005.83.87

[2] Kim, H.-W., Hwang, K.-E., Song, D.-H., Kim, Y.-J., Ham, Y.-K., Lim, Y.-B., Jeong, T.J., Choi, Y.-S. and Kim, C.-J. (2015) Wheat Fiber Colored with a Safflower (Carthamus tinctorius L.) Red Pigment as a Natural Colorant and Anti- 
oxidant in COOKED sausages. LWT-Food Science and Technology, 64, 350-355. http://dx.doi.org/10.1016/j.lwt.2015.05.064

[3] Torabi, B., Adibniya, M. and Rahimi, A. (2015) Seedling Emergence Response to Temperature in Safflower: Measurements and Modeling. International Journal of Plant Production, 9, 393-412.

[4] Wang, Y., Tang, C.Y. and Zhang, H. (2015) Hepatoprotective Effects of Kaempferol 3-O-rutinoside and Kaempferol 3-O-glucoside from Carthamus tinctorius L. on $\mathrm{CCl}_{4}$-Induced Oxidative Liver Injury in Mice. Journal of Food and Drug Analysis, 23, 310-317. http://dx.doi.org/10.1016/j.jfda.2014.10.002

[5] Giayetto, O., Fernandez, E.M., Asnal, W.E., Cerioni, G.A. and Cholaky, L. (1999) Comportamiento de cultivares de cártamo (Carthamus tinctorius L.) enlaregion de Rio Cuarto. Investigación Agraria: Producción y protecciónvegetales, 14, 203-215.

http://www.scielo.br/scielo.php?script=sci_nlinks\&ref=000073\&pid=S0103-8478201200120000700005\&lng=pt

[6] Lovelli, S., Perniola, M., Ferrara, A. and Di Tommaso, T. (2007) Yield Response Factor to Water (Ky) and Water Use Efficiency of Carthamus tinctorius L. and Solanum melongena L. Agricultural Water Management, 92, 73-80. http://dx.doi.org/10.1016/j.agwat.2007.05.005

[7] Kizil, S., Çakmak, Ö., Kirici, S. and İnan, M. (2008) A Comprehensive Study on Safflower (Carthamus tinctorius L.) in Semi-Arid Conditions. Biotechnology \& Biotechnological Equipment, 22, 947-953. http://dx.doi.org/10.1080/13102818.2008.10817585 http://www.tandfonline.com/action/showCitFormats?doi=10.1080/13102818.2008.10817585

[8] Dordas, C.A. and Sioulas C. (2009) Dry Matter and Nitrogen Accumulation, Partitioning, and Retranslocation in Safflower (Carthamus tinctorius L.) as Affected by Nitrogen Fertilization. Field Crops Research, 110, 35-43. http://dx.doi.org/10.1016/j.fcr.2008.06.011

[9] Golzarfar, M., Rad, A.H.S., Delkhosh, B. and Bitarafan, Z. (2011) Changes of Safflower Morphologic Traits in Responseto Nitrogen Rates, Phosphorus Rates and Planting Season. International Journal of Science and Advanced Technology, 1, 84-89. http://www.ijsat.com/admin/download/[11-01-10-037].pdf

[10] El-Mohsen, A.A.A. and Mahmoud, G.O. (2013) Modeling the Influence of Nitrogen Rate and Plant Density on Seed Yield, Yield Components and Seed Quality of Safflower. American Journal of Experimental Agriculture, 3, 336-360. http://dx.doi.org/10.9734/AJEA/2013/2886 http://sciencedomain.org/abstract/1116

[11] Mohamed, S.J., Jellings, A.J. and Fuller, M.P. (2013) Positive Effects of Elevated $\mathrm{CO}_{2}$ and Its Interaction with Nitrogen on Safflower Physiology and Growth. Agronomy for Sustainable Development, 33, 497-505. http://dx.doi.org/10.1007/s13593-013-0137-x http://link.springer.com/article/10.1007\%2Fs13593-013-0137-x

[12] de Anicésio, E.C.A., Bonfim-Silva, E.M., da Silva, T.J.A. and Koetz, M. (2015) Dry Mass, Nutrient Concentration and Accumulation in Safflower (Carthamus tinctorius L.) Influenced by Nitrogen and Potassium Fertilizations. African Journal of Agricultural Research, 9, 552-560. http://www.cropj.com/anicesio_9_6_2015_552_560.pdf

[13] Yau. S.-K. and Ryan, J. (2010) Response of Rainfed Safflower to Nitrogen Fertilization under Mediterranean Conditions. Industrial Crops and Products, 32, 318-323. http://dx.doi.org/10.1016/.jindcrop.2010.05.008

[14] Bonfim-Silva, E.M., Silva, T.J.A., Cabral, E.A., Kroth, B.E. and Rezende, D. (2011) Desenvolvimento Inicial de Gramíneas Submetidas ao Estresse Hídrico. Revista Caatinga, 24, 180-186. http://periodicos.ufersa.edu.br/revistas/index.php/sistema/article/view/1871/4729

[15] Ferreira, D.F. (2011) Sisvar: Um sistema computacional de estatística. Ciência e Agrotecnologia, 35, 1039-1042. http://www.scielo.br/scielo.php?pid=S1413-70542011000600001\&script=sci_arttext

[16] Biscaro, G.A., Machado, J.R., Tosta, M.S., Mendonça, V., Soratto, R.P. and Carvalho, L.A. (2008) Adubação nitrogenada em cobertura no girassol irrigado nas condições de Cassilândia-MS. Ciência e Agrotecnologia, 32, 1366-1373. http://dx.doi.org/10.1590/S1413-70542008000500002 http://www.scielo.br/pdf/cagro/v32n5/02.pdf

[17] da Silva, C.J. (2013) Caracterização agronômica e divergência genética de acessos de cártamo. 51f. Tese. Universidade Estadual Paulista, Faculdade de Ciências Agronômicas, Botucatu. http://www.pg.fca.unesp.br/Teses/PDFs/Arq0958.pdf

[18] Cruz, J.L., Pelacani, C.R., de Carvalho, J.E.B., da Silva Souza Filho, L.F. and Queiroz, D.C. (2007) Níveis de nitrogênio e a taxa fotossintética do mamoeiro "Golden". Ciência Rural, 37, 64-71. http://dx.doi.org/10.1590/S0103-84782007000100011

[19] Braga, C.L. (2009) Doses de nitrogênio no desenvolvimento de girassol ornamental (Helianthusannuus L.) de vaso. 92f. Dissertação. Universidade Estadual Paulista, Faculdade de Ciências Agronômicas, Botucatu. http://base.repositorio.unesp.br/handle/11449/93472

[20] Broge, N.H. and Leblanc, E. (2001) Comparing Prediction Power and Stability of Broadband and Hyperspectral Vegetation Indices for Estimation of Green Leaf Area Index and Canopy Chlorophyll Density. Remote Sensing of Environment, 76, 156-172. http://dx.doi.org/10.1016/S0034-4257(00)00197-8 
[21] Dordas, C.A. and Sioulas, C. (2008) Safflower Yield, Chlorophyll Content, Photosynthesis, and Water Use Efficiency Response to Nitrogen Fertilization under Rainfed Conditions. Industrial Crops and Products, 27, 75-85. http://dx.doi.org/10.1016/j.indcrop.2007.07.020

[22] Elfadl, E., Reinbrecht, C., Frick, C. and Claupein, W. (2009) Optimization of Nitrogen Rate and Seed Density for Safflower (Carthamus tinctorius L.) Production under Low-Input Farming Conditions in Temperate Climate. Field Crops Research, 114, 2-13. http://dx.doi.org/10.1016/j.fcr.2009.06.012

[23] Dordas, C.A., Lithourgidis, A.S., Matsi, T. and Barbayiannis, N. (2008) Application of Liquid Cattle Manure and Inorganic Fertilizers Affect Dry Matter, Nitrogen Accumulation, and Partitioning in Maize. Nutrient Cycling in Agroecosystems, 80, 283-296. http://dx.doi.org/10.1007/s10705-007-9143-1 http://link.springer.com/article/10.1007\%2Fs10705-007-9143-1

[24] Koutroubas, S.D., Papakosta, D.K. and Doitsinis, A. (2008) Nitrogen Utilization Efficiency of Safflower Hybrids and Open-Pollinated Varieties under Mediterranean Conditions. Field Crops Research, 107, 56-61.

http://dx.doi.org/10.1016/j.fcr.2007.12.009 